\title{
Giant Left Atrial Myxoma Prolapsed To Left Ventricule With Every Cardiac Cyclus Operated With Biatrial Transseptal Incision
}

\author{
Her Kardiyak Siklusta Mitral Kapaktan Prolabe Olan, \\ Biatriyal Transseptal Insizyon Ile Opere Edilen Dev Sol Atriyal Miksoma
}

\section{Hakan Saçlı, Alper Erkin, Bilal Perçin, Mehmet Kaan Kırali}

Kalp ve Damar Cerrahi Ana Bilim Dalı, Sakarya Üniversitesi Eğitim ve Araştırma Hastanesi, Sakarya

Intrakardiyak tümörlerin çoğu benign karakterde olup, en sık gözlenen benign kardiyak tümör miksomadır. Benign karakterde olmasına rağmen tedavi edilmediği süreçte mortalite ve morbiditeye etki edecek komplikasyonlara sebebiyet verebilir. 40 yaşında kadın hasta göğüs hastalıkları polikliniğine sık sık nefes darlığı şikayeti ile başvurdu ve çekilen ekokardiyografide sol atriyum içerisinde mitral kapaktan sol ventrikül içerisine prolabe olan $5 \times 3 \mathrm{~cm}$ çapında kitle gözlendi. Sol vetrikül sistolik fonksiyonları normal olup, hafif-orta mitral kapak yetmezliği gözlendi ve PABs: $75 \mathrm{mmHg}$ olarak ölçüldü. Preoperatif hazırlıklar sonrası hasta operasyona alındı. Kardiopulmoner bypass'a girilerek, kross klemp konulup cerrahi işleme başlandı. Dubost insizyon kullanılarak kitle eksplore edildi.Kitle interatriyal septuma sapla bağlı olup eksize edildi. Kitle çıkarılıktan sonra mitral kapak koaptasyonu normal idi ve müdahaleye gerek görülmedi. İnteratriyal septum ve atriotomi perikardiyal yama ile onarıldı. Hastanın yoğun bakım ve servis takip süreci normal olup genel durumu iyi şekilde taburcu edildi. Intrakardiyak kitleler sıkıkla benign karekterde de olsa; emboliye yol açabilmeleri, kapak fonksiyonlarına etki etmeleri, trombüs oluşumuna sebebiyet vermeleri nedeniyle tedavi gerektirmektedir. Kitle tamamen rezeke edilmeli ve rekürrensi engellemek için geride kitleye bağlı doku bırakılmamalıdır. Kardiyopulmoner bypass eşliğinde başarıı sonuçlar alınabilmektedir.

Anahtar Kelimeler: Sol atriyal miksoma, Biatrial transseptal insizyon, Dubost İnsizyonu, Kardiyopulmoner Bypass

\section{Abstract}

Received : 26.09.2014 Accepted: 14.10.2014

Primary cardiac tumors are rarely seen.Most of the intracardiac tumors are benign characterised and mainly seen benign cardiac tumor is myxoma. Our patient was 40 years old woman. She is referring with dyspnea complaint to the Chest Diseases clinic for several times. Echocardiography was performed in Cardiology clinic and a giant left atrial mass (myxoma; $5 \times 3 \mathrm{~cm}$ diameter) prolapsed to left ventricle through mitral valve with every cardiac cycle was seen. Left ventricle ejection fraction was normal, PABs was $75 \mathrm{mmHg}$ and mild to moderate mitral valve insufficiency was seen. Operation performed with cardiopulmonary bypass and after cross clamping to aorta Dubost's biatrial transseptal incision done.Myxoma was originated from interatrial septum. Myxoma resected and after resection mitral valve assessed; leaflet coaptation and anotomy were normal.Interatrial septum and atrium was repaired with pericardial patch. Intensive care unit and service follow-up of the patient was normal. Postoperative echocardiography has done and PABs decreased to $35 \mathrm{mmHg}$, mitral valve insufficiency has decreased too. Patient was discharged as healthy. Even though intracardiac tumors are benign characterised; these tumors can cause embolisation, thrombus formation and valve incompetence and etc.Successful results can be obtained in the presence of cardiopulmonary bypass and surgeon should be aware of resecting the tumor completely to prevent recurrence.

Keywords: Left atrial myxoma, Biatrial transseptal incision, Dubost's incision, Cardiopulmonary bypass 


\section{Introduction}

Primary cardiac tumors are rarely seen, with a reported incidence of $0,0017 \%$ to $0,19 \%$ (approximately $\% 0,02)^{1,2}$. Most of the cardiac tumors are bening characterised (\%75) and most of them are myxomas (\%40-50 $)^{3,4}$. We want to present a case of giant left atrial myxoma with a symptom of dyspnea.

\section{Case}

Our patient was 40 years old woman. She was $156 \mathrm{~cm}$ height, $65 \mathrm{~kg}$ weight and BSA (body surface area) was 1,8 $\mathrm{m}^{2}$. She is referring with dyspnea complaint to the Chest Diseases clinic for several times. She was admitted to the emergency room with dyspnea, mild lung edema and pretibial edema at the last time. Echocardiography was performed in Cardiology clinic; and a giant left atrial mass (myxoma; $5 \times 3 \mathrm{~cm}$ diameter) prolapsed to left ventricle through mitral valve with every cardiac cycle was seen (Picture 1). Left ventricle ejection fraction was normal, PABs was $75 \mathrm{mmHg}$ and mild to moderate mitral valve insufficiency was seen. Her NYHA class was 3-4 so she followed in intensive care unit before operation. Diuretic medications were given to provide negative fluid balance. After the patients clinical status improved after medical theraphy and preoperative preparations she delivered to the operation. Operation performed with cardiopulmonary bypass and after cross clamping to aorta Dubost's biatrial transseptal incision $^{5}$ done. Myxoma was originated from interatrial septum (Picture 2). Myxoma resected and after resection mitral valve assessed; leaflet coaptation and anotomy were normal (Picture 3 and 4). Interatrial septum and atrium was repaired with pericardial patch. Intensive care unit and service follow-up of the patient was normal. Postoperative echocardiography has done and PABs decreased to $35 \mathrm{mmHg}$, mitral valve insufficiency has decreased too. Patient was discharged and followed as healthy for 6 months.

\section{Discussion}

As we know that cardiac tumors are rarely seen most of them are originated from left atrium and rarely from right atrium3. In some cases tumoral mass originate from interatrial septum and ventricule. It is more frequent in females; sometimes can be familial; and the mean age of appareance of myxomas is approximately 50 years ${ }^{6,7}$.

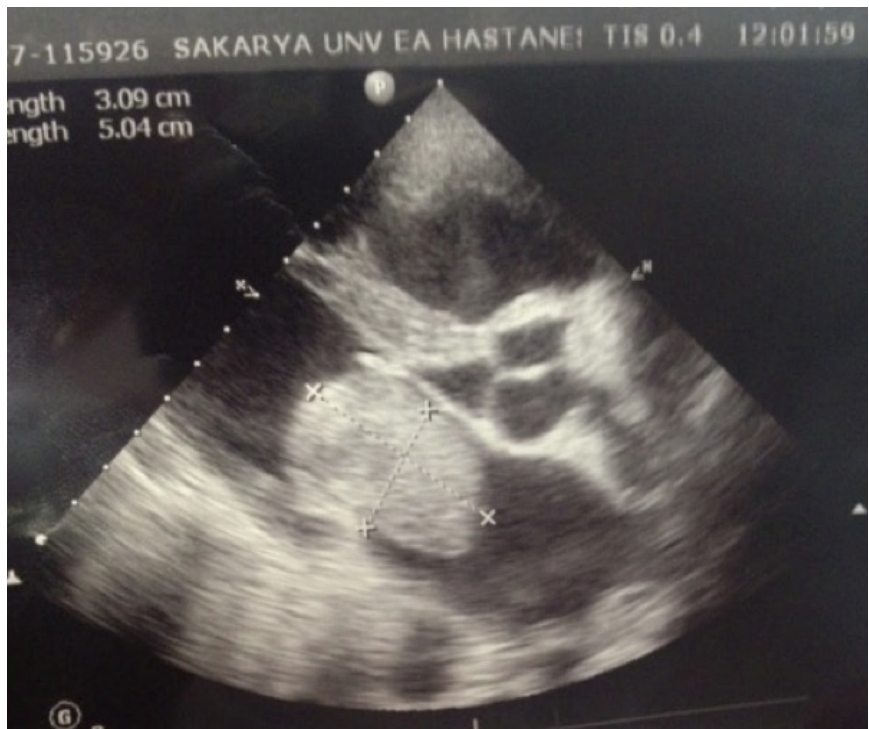

Picture 1: Preoperative Echocardiographic image of myxoma prolabing from mitral valve.

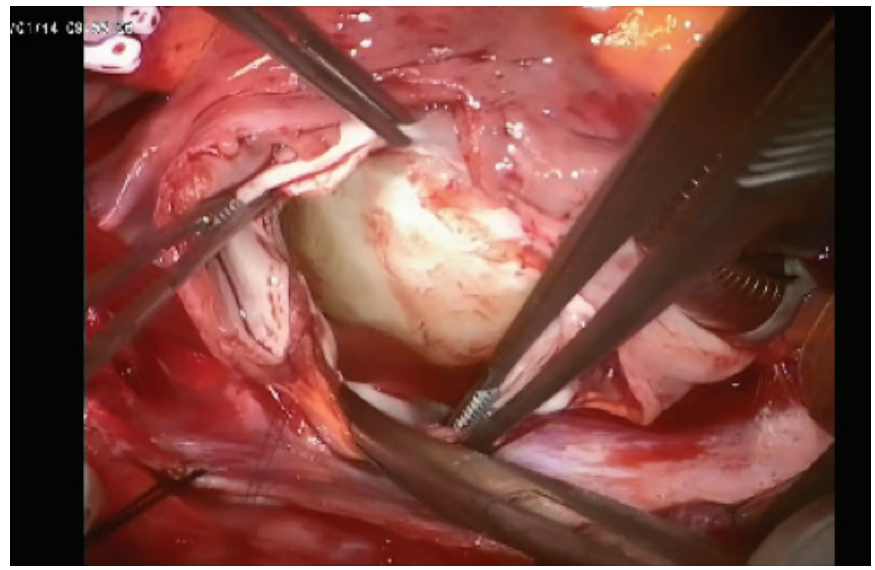

Picture 2: After Biatrial transseptal incision(Dubost's incision) myxoma is seen in left atrium.

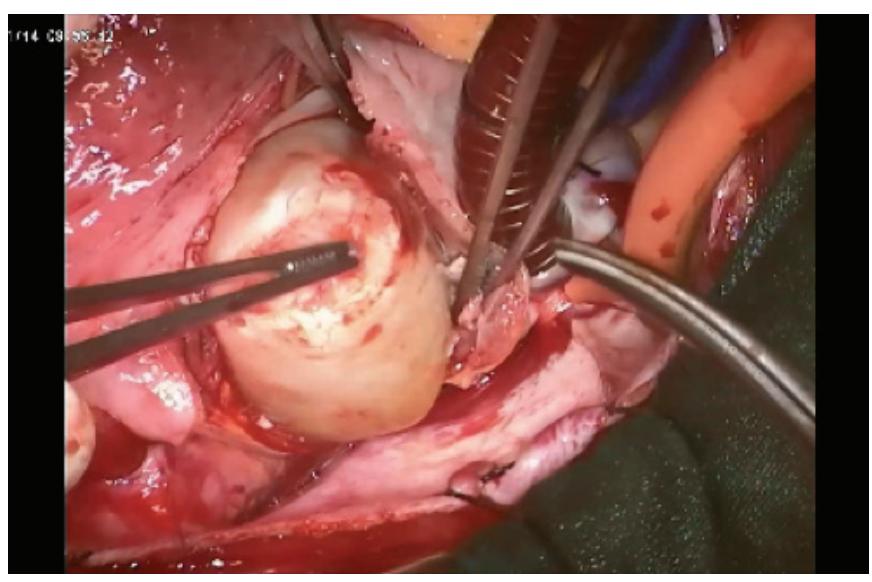

Picture 3: Myxoma is taken out from the left atrium. 


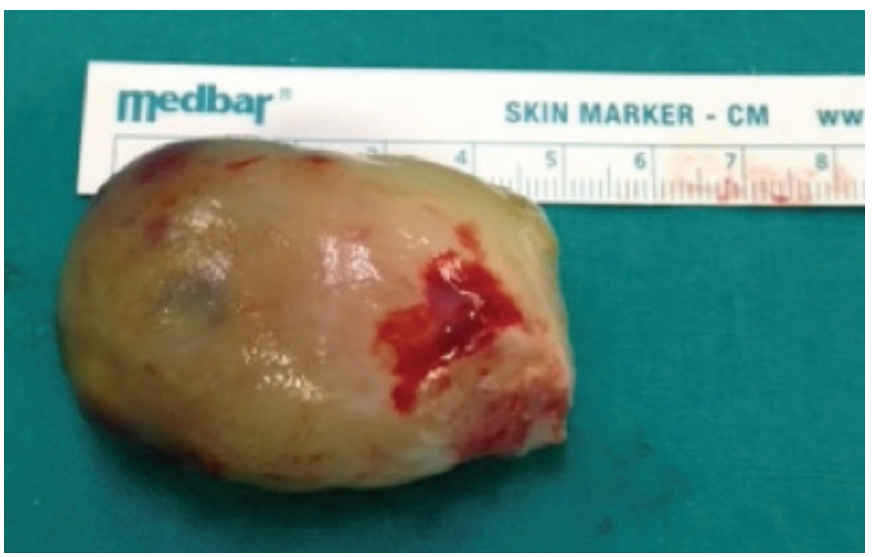

Picture 4: Myxoma is seen after resection.

Clinical manifestations are presenting in a wide range. It can cause constitutional sypmtoms such as fatigue, fever, malaise, weight loss, arthralgia, night sweets. But they can cause cardiac symptoms such as arryhythmia, pulmonary hypertension, congestive heart failure, pericardial involvement, chest pain. These sypmtoms are because of the obstruction in cardiac cavities and valves. Obstruction results from dyspnea, orthopnea to sudden death ${ }^{8}$. Embolization to several focuses can be the first sign of the cardiac tumors; this can be in one third of all patients especially cerebral arteries, visceral, renal and coronary arteries ${ }^{1,8}$. Because of the mechanical destruction of the mass hemoliytic anemia and thrombocytopenia can ocur ${ }^{3}$.

Diagnoses can be made by ecocardiography and computed tomography. Physical examination, laboratory findings and chest $X$ ray is helpful for diagnoses and follow up.

Operation has to be done with cardioplumonary bypass. Approach to the tumoral mass has got several way. Left atriotomy and biatrial approach are the most common two ways to reach the tumoral mass but Dubost's biatrial transseptal incision as we done is not common as the other techniqes. Some tumoral mass is derived from the atrial wall beneath to the interatrial septum, and if the tumoral mass is so big as in our case it is more complicated to open classic incisions. So a biatrial transseptal incision is advantageous to manage the cardiac tumors like this situation.

Recurrence of the cardiac tumor is the most important complication after the long follow period of the operation. Recur- rence rates are between $\% 1$ and $\% 3$ for sporadic myxomas ${ }^{7,8}$. A complete resection of the tumor has to be done to avoid such a situation like this.

\section{Conclusion}

Even though intracardiac tumors are benign characterised; these tumors can cause embolisation, thrombus formation and valve incompetence and etc. Successful results can be obtained in the presence of cardiopulmonary bypass and surgeon should be aware of resecting the tumor completely to prevent recurrence. 
1. Reynen K, Cardiac Myxomas. N Engl J Med. 1995; 333: 1610-17

2. Reynen $\mathrm{K}$, Frequency of primary tumors of the heart. The American J Card 1996;77(1):107

3. Silverman NA, Primary Cardiac Tumors. Ann Surg. 1980;191(2): 127-138

4. Rengan R, Thomas Jr. CR, Primary Cardiac Tumors. Encyclopeida of Radiation Oncology 2013; pp 647-649

5. Dubost C, Guilmet D, de Parades B, Pedeferri G, New technic of opening of the left auricle in open-heart surgery: the transseptal bi-auricular approach. Press Med 1966; 74: 1607-1608

6. Gavrielatos G, Letsas KP, Pappas LK, Dedeilias P, Sioras E, Kardaras F. Large left atrial myxoma presented as fever of unknown origin: a challenging diagnosis and a review of the literature. Cardiovasc Pathol. 2007; 6: 365-367

7. Akhtar J, Wasay M, Rauf J, Unusual presentation of more common diseaselinjury Atrial myxoma: a rare cause of cardioembolic stroke. BMJ Case Reports Sep 7 2012; 1-3

8. Lazaros G, Masoura C, Brili S, Stavropoulos G, Kafiri G, Stefanadis C . Large Left Atrial Myxoma in an Oligosymptomatic Young Woman. Hellenic J Cardiol 2013; 54: $60-63$ 